\title{
A TEST FOR COELIAC DISEASE
}

\author{
BY \\ W. W. PAYNE and V. JENKINSON \\ From The Hospital for Sick Children, Great Ormond Street, London
}

(RECEIVED FOR PUBLICATION APRIL 28, 1958)

The relationship between wheat flour in the diet and the development of symptoms in children with coeliac disease observed by Dicke (1950) has been established. Subsequent investigations indicated that the injurious factor occurs principally in the gliadin fraction (van de Kamer, Weijers and Dicke, 1953). Weijers and van de Kamer (1955) used gliadin in a method of testing wheat sensitivity hoping that the test would be helpful in the diagnosis of coeliac disease.

In order to determine the value of this gliadin tolerance test, it was performed on a series of children with coeliac disease and on controls. The children with coeliac disease were patients of Dr. Wilfrid Sheldon and attended his clinic regularly. The diagnostic criteria used were those given by May (in Garrod, Batten and Thursfield, 1947). The diagnosis was confirmed by a favourable response to a diet free of wheat and rye gluten. The beneficial effect of the diet is manifested by an improvement in appetite and temperament, disappearance of steatorrhoea and an increase in growth. Growth is carefully followed by height and weight charts (Sheldon and Lawson, 1952).

\section{Material}

Thirty-three cases of coeliac disease were studied. The diagnosis was made according to the criteria stated in 25 cases. In eight cases the diagnosis was based on clinical data associated with the response to a gluten-free diet, and relevant biochemical investigations were not made.

The children were in all stages of the disease and treatment. Two of the children were in the active phase. Treatment had not been instituted when they were tested. Eight children had been on a gluten-free diet for periods of a few days to one month before their gliadin tolerance test. These children have since shown a satisfactory response to the therapeutic diet. The rest of the cases had been treated for some years, having had periods on a gluten-free diet and on a normal diet. Some children, who had been treated for more than four years, still deteriorated when returned to a normal diet. A few patients had apparently recovered after prolonged treatment; they had shown no recurrence of symptoms when returned to a normal diet and growth continued at the expected rate. Six children in this series were either undiagnosed or untreated for a long time after the onset of symptoms.

Control cases were selected from convalescent patients who had had diseases with no alimentary tract involvement, with the exception of one child, who was a normal healthy unlike twin of one of the coeliac patients. Four children who were convalescent from disorders of the alimentary tract from causes other than coeliac disease formed a second control group. A summary of the details of these cases is tabulated:

\begin{tabular}{|c|c|c|c|}
\hline Case & Sex & $\begin{array}{l}\text { Age } \\
(\text { Yr. })\end{array}$ & Diagnosis \\
\hline A.H. & . . ㅇ.. & $2 \frac{1}{2} .$. & Dyschezia \\
\hline N.H. & $\cdots \delta^{\pi} \cdots$ & $7 \frac{1}{2}$. & $\begin{array}{l}\text { Malabsorption syndrome with abnormal pattern } \\
\text { of second part of duodenum. }\end{array}$ \\
\hline S.T. & $\ldots q$. & 11. & $\begin{array}{l}\text { Chronic constipation with faecal incontinence. } \\
\text { Congenital anal stenosis. Operation: division of } \\
\text { fibrosed anal ring. Faecal incontinence con- } \\
\text { tinued. Vaginal septum. }\end{array}$ \\
\hline
\end{tabular}

M.K. . . . . 11 . Chronic watery diarrhoea. Giardia cysts found. Congenital atrial septal defect.

Gliadin was prepared according to the procedure recommended by van de Kamer (personal communication). The patient to be tested fasted, usually, for 12 hours; the period of fast was sometimes reduced to eight hours when the condition of the patient made it advisable, e.g. in the case of a young ailing child. A sample of blood was taken by fingerprick from a fasting subject into a heparinized tube. A dose of gliadin (350 mg./Kg. body weight) in water was fed to the patient, and hourly samples of blood were taken for five consecutive hours.

The plasma glutamine was estimated in each sample as glutamic acid (Prestcott and Waelsch, 1946, 1947). Free glutamic acid was removed by adsorption on acid alumina. The filtrate was hydrolyzed in acid medium 
for one hour. The glutamic acid set free was separated on acid alumina and estimated. A glutamic acid standard was used in place of the solution recommended by Prestcott and Waelsch (1946). A series of standard curves were made and found to be linear over a range of 0-25 $\gamma$ glutamic acid. A standard sample was estimated in parallel with test samples and all readings were related to it. The average difference between repeat estimations of 50 test samples drawn at random from our results was $0.7 \mathrm{mg} . / 100 \mathrm{ml}$. Duplicate estimations were done when possible. It has been assumed that the glutamic acid liberated by short acid hydrolysis of the filtrate was entirely derived from the plasma glutamine; since other glutamine-containing compounds may contribute the measured substance is known as 'apparent' plasma glutamine (Prestcott and Waelsch, 1947).

\section{Recording of Results}

The maximum increase of apparent plasma glutamine occurred at variable times. The greatest increase, irrespective of time of occurrence, is recorded as a percentage of the fasting value, which is the form adopted by Weijers and van de Kamer (1955). There is no reason to suppose that there is any relation between the fasting plasma glutamine and the absolute increase after gliadin; therefore, the absolute increase in $\mathrm{mg}$./ $100 \mathrm{ml}$. is also recorded. The results are given in the following tables.

Table 1 shows that the mean maximum increment of apparent plasma glutamine of these children with coeliac disease is significantly greater than that of normal children. A few children who had recently recovered from dysfunction of the alimentary tract show a mean percentage rise which is intermediate between that of normal children and coeliac children. The mean percentage in this group is not significantly different from children with no recent gastrointestinal disturbance, nor from coeliac children. The absolute rise is the same as that of coeliac children.

Tables $2 a$ and $b$ show that there is no relation between age and magnitude of increase of apparent plasma glutamine in this series of controls and coeliac patients. The numbers of control children in different age groups are insufficient for a complete analysis, but there is no indication of an age relationship (Table 2a). Age can be disregarded when grouping the coeliac patients according to a clinical assessment (Table 2b).

Table 3 shows that the mean rise of apparent plasma glutamine of children treated for less than two years is significantly greater than that of normal children. Children who remained intolerant of gluten even after four years of treatment show a similar difference. There is no correlation in this series between magnitude of rise of apparent plasma
TABLE 1

\begin{tabular}{|c|c|c|c|c|c|}
\hline & \multirow[t]{2}{*}{$\begin{array}{l}\text { No. of } \\
\text { Estima- } \\
\text { tions }\end{array}$} & \multicolumn{4}{|c|}{$\begin{array}{l}\text { Maximum Increment of Apparent } \\
\text { Plasma Glutamine } \\
\begin{array}{l}\text { As } \% \text { of fasting } \\
\text { value }\end{array}\end{array}$} \\
\hline & & Mean & S.D. & Mean & S.D. \\
\hline $\begin{array}{l}\text { Controls: } \\
\text { Group } 1 \ldots\end{array}$ & 13 & $22 \cdot 62$ & $21 \cdot 53$ & $1 \cdot 04$ & $1 \cdot 10$ \\
\hline $\begin{array}{l}\text { Group } 2 \ldots \\
\text { Children with } \\
\text { recent alimentary } \\
\text { dysfunction }\end{array}$ & 5 & $40 \cdot 80$ & $17 \cdot 55$ & $2 \cdot 42$ & $1 \cdot 21$ \\
\hline Coeliac patients & 38 & $51 \cdot 24$ & $37 \cdot 32$ & $2 \cdot 42$ & $1 \cdot 38$ \\
\hline
\end{tabular}

Significance of difference between means of:

$\begin{array}{lll}\text { Control groups } 1 \text { and 2: } & \mathbf{P}>0.05 & \mathbf{P}>0.05 \\ \text { Control group } 1 \text { and coeliac group: } & \mathbf{P}<0.01 & \mathbf{P}<0.01 \\ \text { Control group 2 and coeliac group: } & \mathbf{P}>0.05 & \mathbf{P}>0.05\end{array}$

Using Cochran's approximation.

TABLE 2A

\begin{tabular}{|c|c|c|c|c|c|}
\hline \multirow[t]{2}{*}{$\begin{array}{l}\text { Control Children } \\
\text { recovered from } \\
\text { Diseases with no } \\
\text { Alimentary Tract } \\
\text { Involvement }\end{array}$} & \multirow[t]{2}{*}{$\begin{array}{l}\text { No. of } \\
\text { Estima- } \\
\text { tions }\end{array}$} & \multicolumn{4}{|c|}{$\begin{array}{l}\text { Maximum Increment of Apparent } \\
\text { Plasma Glutamine }\end{array}$} \\
\hline & & Mean & S.D. & Mean & S.D. \\
\hline $0-4$ yr. & 2 & 11 & & 0.75 & \\
\hline $5-9$ yr. & 6 & $30 \cdot 67$ & $20 \cdot 62$ & $1 \cdot 42$ & $1 \cdot 06$ \\
\hline $10-14$ yr. & 5 & $12 \cdot 4$ & $22 \cdot 01$ & $0 \cdot 70$ & $1 \cdot 18$ \\
\hline
\end{tabular}

TABLE 2B

\begin{tabular}{|c|c|c|c|c|c|}
\hline \multirow[t]{2}{*}{ Coeliac Patients } & \multirow[t]{2}{*}{$\begin{array}{l}\text { No. of } \\
\text { Estima- } \\
\text { tions }\end{array}$} & \multicolumn{4}{|c|}{$\begin{array}{l}\text { Maximum Increment of Apparent } \\
\text { Plasma Glutamine } \\
\begin{array}{l}\text { As } \% \text { of fasting } \\
\text { value }\end{array}\end{array}$} \\
\hline & & Mean & S.D. & Mean & S.D. \\
\hline $0-4 \mathrm{yr}$. & 13 & $54 \cdot 23$ & $40 \cdot 91$ & $2 \cdot 24$ & $1 \cdot 39$ \\
\hline $5-9$ yr. & 19 & $55 \cdot 37$ & $38 \cdot 76$ & $2 \cdot 71$ & $1 \cdot 46$ \\
\hline $10-14$ yr. & 6 & $31 \cdot 67$ & $18 \cdot 34$ & $1 \cdot 88$ & $1 \cdot 01$ \\
\hline
\end{tabular}

Significance of difference between means of:

0-4 yr. and 5-9 yr. $\quad P>0.05 \quad P>0.05$

0-4 yr. and 10-14 yr. $P>0.05 \quad P>0.05$

5-9 yr. and 10-14 yr. P $>0.05 \quad P>0.05$

Using Cochran's approximation.

glutamine and phase of the disease, whether symptoms are active or controlled by treatment.

The number of children who, after prolonged treatment, no longer appeared intolerant of gluten, was small. The mean rise of plasma glutamine did not differ significantly from normal children, but this may be the result of the limited size of the sample.

The six patients who remained undiagnosed or untreated for some time after the appearance of the disease were grouped together, but they do not form a homogeneous group. It is not surprising that their response to gliadin is variable. 
TABLE 3

\begin{tabular}{|c|c|c|c|c|c|}
\hline \multirow[t]{2}{*}{$\begin{array}{l}\text { Independent Clinical } \\
\text { Assessment of } \\
\text { Children Tested }\end{array}$} & \multirow[t]{2}{*}{$\begin{array}{l}\text { No. of } \\
\text { Estima- } \\
\text { tions }\end{array}$} & \multicolumn{4}{|c|}{$\begin{array}{l}\text { Maximum Increment of Apparent } \\
\text { Plasma Glutamine } \\
\begin{array}{c}\text { As } \% \text { of fasting } \\
\text { value }\end{array}\end{array}$} \\
\hline & & Mean & S.D. & Mean & S.D. \\
\hline $\begin{array}{l}\text { Controls: } \\
\text { Group I .. }\end{array}$ & 13 & $22 \cdot 62$ & $21 \cdot 53$ & $1 \cdot 04$ & $1 \cdot 10$ \\
\hline $\begin{array}{l}\text { Group } 2 \text {. } \\
\text { Children with ali- } \\
\text { mentary dysfunc- } \\
\text { tion }\end{array}$ & 5 & $40 \cdot 80$ & $17 \cdot 55$ & $2 \cdot 42$ & $1 \cdot 81$ \\
\hline $\begin{array}{l}\text { Coeliac Patients: } \\
\text { All cases treated } \\
\text { less than } 2 \text { yr. }\end{array}$ & 14 & $51 \cdot 57$ & $40 \cdot 57$ & $2 \cdot 19$ & $1 \cdot 36$ \\
\hline $\begin{array}{l}\text { Intolerant of glu- } \\
\text { ten after more } \\
\text { than } 4 \text { yr. treat- } \\
\text { ment }\end{array}$ & 14 & 52.07 & $31 \cdot 26$ & $2 \cdot 65$ & 1.05 \\
\hline $\begin{array}{l}\text { Recovered after } \\
\text { long treatment }\end{array}$ & 4 & $45 \cdot 50$ & $35 \cdot 24$ & $2 \cdot 38$ & $1 \cdot 96$ \\
\hline $\begin{array}{l}\text { Treatment com- } \\
\text { menced late } \\
\text { after onset of } \\
\text { symptoms }\end{array}$ & 6 & $52 \cdot 33$ & $52 \cdot 14$ & $2 \cdot 48$ & $1 \cdot 92$ \\
\hline
\end{tabular}

Significance of difference between means of:

Control and coeliac patients:

(a) Treated for less than $2 \mathrm{yr}$. $\quad \mathbf{P}<0.05 \quad \mathbf{P}<0.05$

(b) Intolerant of gluten after more than 4 yr. treatment.

$\begin{array}{lll}P & P>0.05 & P>0.05\end{array}$

$\begin{array}{lll}\text { (d) Treatment commenced late after } & & \\ \text { onset of symptoms. } & P>0.05 & P>0.05\end{array}$ Using Cochran's approximation. may occur in normal children over a lower range, but in this case the trend was not significant. Further estimations are necessary to substantiate the indications of a rise of fasting level with age.

Table 4 shows that five children, who were tested while on a gluten-free diet and while on a normal diet, demonstrated no relationship between diet and rise of plasma glutamine.

In Table 5 the coeliac children were grouped according to the diet at the time of the test. The similarity of the mean rise in the two groups supports the conclusion that diet has no influence on the test.

None of the children with coeliac disease showed aggravation or recurrence of symptoms after the dose of gliadin used in the test.

\section{Discussion}

These results confirm the observations of Weijers and van de Kamer (1955), who found a greater increase of plasma glutamine in coeliac children than in normal children after ingestion of gliadin. The increase in our series of coeliac patients is not as great as that found by Weijers and van de Kamer. Alvey, Anderson and Freeman (1957), also found after a test dose of gluten an increase in blood glutamine which was greater in four coeliac children

TABLE 4

\begin{tabular}{|c|c|c|c|c|c|c|c|c|c|c|}
\hline \multirow{3}{*}{\multicolumn{2}{|c|}{ Patient }} & \multirow[b]{3}{*}{ Age (yr.) } & \multicolumn{4}{|c|}{ Effect of Diet on Increase of Apparent Plasma } & \multicolumn{4}{|l|}{ Glutamine } \\
\hline & & & \multicolumn{4}{|c|}{ Gliadin Tolerance Test 1} & \multicolumn{4}{|c|}{ Gliadin Tolerance Test 2} \\
\hline & & & Diet & $\begin{array}{l}\text { Period of } \\
\text { Diet (mth.) }\end{array}$ & \multicolumn{2}{|c|}{\begin{tabular}{c|c} 
Maximum Increment of \\
Plasma Glutamine \\
$\%$
\end{tabular}} & Diet & $\begin{array}{l}\text { Period of } \\
\text { Diet (mth.) }\end{array}$ & \multicolumn{2}{|c|}{$\begin{array}{l}\text { Maximum Increment of } \\
\text { Plasma Glutamine }\end{array}$} \\
\hline C.I. & $\ldots$ & 14 & G.F.D. & 28 & 9 & $0 \cdot 6$ & Normal & 6 & 26 & $2 \cdot 0$ \\
\hline M. McC. & $\ldots$ & 8 & G.F.D. & 30 & 45 & $1 \cdot 7$ & Normal & 4 & 41 & $3 \cdot 6$ \\
\hline C.M. & $\cdots$ & 3 & G.F.D. & 15 & 77 & $4 \cdot 3$ & Normal & 5 & 13 & $1 \cdot 2$ \\
\hline L.P. & $\ldots$ & 7 & Normal & 33 & 38 & $3 \cdot 1$ & G.F.D. & 8 & 79 & $4 \cdot 2$ \\
\hline J.A. & $\ldots$ & 7 & Normal & 18 & 98 & $5 \cdot 3$ & G.F.D. & 4 & 23 & $1 \cdot 1$ \\
\hline
\end{tabular}

G.F.D. = Gluten free diet.

Comparison of the mean rise of apparent plasma glutamine as a percentage of the fasting value of children who remained intolerant of gluten even after prolonged treatment and that of normal controls shows that the probability of the difference between the two results being due to chance, lies between 1 in 20 and 1 in 100 . When the increase in mg./100 ml. is used instead, the probability is less than 1 in 100 . The explanation of the difference lies in the fact that the fasting level of plasma glutamine tended to increase with age in these coeliac children. There are indications that the same trend

TABLE 5

\begin{tabular}{|c|c|c|c|c|c|}
\hline \multirow[t]{2}{*}{ Diet } & \multirow[t]{2}{*}{$\begin{array}{c}\text { No. of } \\
\text { Estimations on } \\
\text { Coeliac Children }\end{array}$} & \multicolumn{4}{|c|}{$\begin{array}{l}\text { Maximum Increment of Apparent } \\
\text { Plasma Glutamine } \\
\begin{array}{l}\text { As } \% \text { of fasting } \\
\text { value }\end{array} \text { mg. } / 100 \mathrm{ml} .\end{array}$} \\
\hline & & Mean & S.D. & Mean & S.D. \\
\hline Gluten free & 28 & $51 \cdot 18$ & $35 \cdot 85$ & $2 \cdot 29$ & $1 \cdot 29$ \\
\hline Normal & 10 & $51 \cdot 40$ & $43 \cdot 24$ & $2 \cdot 67$ & $1 \cdot 74$ \\
\hline
\end{tabular}


than in four normal children, but the increment was again of a lesser degree than that reported by Weijers and van de Kamer.

The intermediate position of children convalescent from gastro-intestinal disorders other than gluteninduced coeliac disease suggests that the abnormal increase of plasma glutamine may be a non-specific effect common to other gastro-intestinal disturbances. The number of these children tested was too small to show conclusive evidence.

The increase of plasma glutamine measured in five children tested while on a gluten-free diet and on a normal gluten-containing diet showed no correlation with the prevailing diet. The results from these children exhibit considerable variation between two tests in the same child. A very wide standard deviation is evident in this series indicating an overlap in the range of results from the various groups. The variance found in the results from the coeliac group is significantly greater than that in the control group of children with no recent gastrointestinal dysfunction (Table 1). This probably reflects the unreliability of a test dependent on rate of absorption in children where absorption is disturbed (Alvey, et al., 1957). We would conclude in accordance with other workers that the test in its present form is unreliable in individual cases.

Later experiments by van de Kamer and Weijers (1955) showed that it was glutamine bound in protein, as it occurs in gliadin, which probably caused the abnormal increase of apparent plasma glutamine in children with coeliac disease and was the injurious factor. Frazer (1956) reported the presence of abnormally large amounts of a glutamine-containing peptide in the blood of one patient fed with a peptide fraction obtained from a tryptic digest of wheat gluten. The toxicity of this fraction was eliminated after digestion by an extract of pig's intestinal mucosa. The work of Alvey et al. (1957) substantiates the evidence indicating that the toxic factor in gluten is probably a peptide. They were able to show that the smaller peptides of gluten caused an increase of fat excretion in a patient with mild clinical symptoms.

The difference between normal children and children with coeliac disease is sufficiently pronounced to encourage further investigation of the amino-acid and peptide pattern of the blood after ingestion of gliadin or fractions of this protein.

\section{Summary}

A gliadin tolerance test was performed on control children and children with coeliac disease.

The increase of apparent plasma glutamine after a test dose of gliadin is significantly greater in children with coeliac disease than in control children convalescent from diseases with no gastro-intestinal involvement. A small group of children convalescent from gastro-intestinal dysfunction from causes other than coeliac diseases showed an increase intermediate between normal controls and coeliac children.

There is no quantitative relation between increase of plasma glutamine and phase of the disease, whether acute or non-symptomatic through withdrawal of wheat and rye gluten from the diet.

Diet appears to have no influence on the degree of increase of plasma glutamine.

The overlap of range of results from controls and coeliac patients is considerable and does not recommend the test as a diagnostic one.

We wish to thank Dr. Wilfrid Sheldon and other members of the staff for allowing us access to their patients. We are grateful to Dr. Sheldon for his help and interest in the study and to Dr. C. O. Carter for his tuition and advice on methods of statistical analysis. We are also indebted to Mr. A. Whitfield for his skilled assistance in the laboratory.

This investigation was done under the auspices of the Research Committee, The Hospital for Sick Children, Great Ormond Street.

\section{REFERENCES}

Alvey, C., Anderson, C. M. and Freeman, M. (1957). Arch. Dis. Childh., 32, 434.

Dicke, W. K.' (1950). Coeliakie. M.D. Thesis. Utrecht.

Frazer, A. C. (1956). Proc. roy. Soc. Med., 49, 1009.

Garrod, A. E., Batten, F. E. and Thursfield, H. (1947). Diseases of Children. 4th ed. Edited by Paterson, D. and Moncrieff, A. A., 1, 343. London.

Kamer, J. H. van de. Personal communication.

- and Weijers, H. A. (1955). Acta paediat. (Uppsala), 44, 465. - - - and Dicke, W. K. (1953). Ibid., 42, 223.

Prestcott, B. A. and Waelsch, H. (1946). J. biol. Chem., 164, 331. - (1947). Ibid., 167, 855.

Sheldon, W. and Lawson, D. (1952). Lancet, 2, 902. Weijers, H. A. and Kamer, J. H. van de (1955). Acta paediat.
(Uppsala), 44, 536. 